\title{
High-level dietary crude protein decreased backfat thickness and increased carcass yield score in finishing Hanwoo beef cattle (Bos taurus coreanae)
}

\author{
Seoyoung Jeon ${ }^{1}$, Mingyung Lee ${ }^{1}$, Jakyeom Seo ${ }^{1,2}$, Jeong-Hoon Kim³, \\ Dong-Keun $\mathrm{Kam}^{3}$ and Seongwon Seo ${ }^{1 *}$ \\ ${ }^{1}$ Division of Animal and Dairy Sciences, Chungnam National University, Daejeon 34134, Korea \\ ${ }^{2}$ Life and Industry Convergence Research Institute, Department of Animal Science, Pusan National \\ University, Miryang 50463, Korea \\ ${ }^{3}$ Cargill Agri Purina, Seongnam 13630, Korea
}

Received: May 17, 2021

Revised: Aug 1, 2021

Accepted: Aug 18, 2021

*Corresponding author

Seongwon Seo

Division of Animal and Dairy Sciences,

Chungnam National University,

Daejeon 34134, Korea.

Tel: +82-42-821-5787

E-mail: swseo@cnu.kr

Copyright (? 2021 Korean Society of Animal Sciences and Technology.

This is an Open Access article distributed under the terms of the Creative Commons Attribution

Non-Commercial License (http:// creativecommons.org/licenses/by$\mathrm{nc} / 4.0 /$ ) which permits unrestricted non-commercial use, distribution, and reproduction in any medium, provided the original work is properly cited.

ORCID

Seoyoung Jeon

https://orcid.org/0000-0002-8276-317X Mingyung Lee

https://orcid.org/0000-0001-8952-9725 Jakyeom Seo

https://orcid.org/0000-0002-9176-5206 Jeong-Hoon Kim

https://orcid.org/0000-0003-4546-7694

Dong-Keun Kam

https://orcid.org/0000-0001-8778-5979

Seongwon Seo

https://orcid.org/0000-0002-4131-0545

\section{Abstract}

Recently, a high level of dietary crude protein (CP) has become of interest as a possible practice to improve the carcass quality of beef cattle, and its level has been increasing in the field. However, there is little scientific evidence that supports this. This study was conducted to test whether a high dietary CP level would improve growth performance, body metabolism, and carcass traits in Hanwoo beef cattle. A total of 32 Hanwoo finishing beef cattle (18 multiparous cows, six heifers, and eight steers) participated in a 12-weeks feeding trial. Two kinds of total mixed rations were prepared to contain two different $\mathrm{CP} ; 156 \mathrm{~g} / \mathrm{kg}$ for the control (CON) and $173 \mathrm{~g} / \mathrm{kg}$ of $\mathrm{CP}$ for the treatment (HCP), while maintaining a similar level of metabolizable energy. The experiment was ended when more than half of the steers reached the target body weight $(730 \mathrm{~kg})$. Blood was collected at the end of the experiment. After harvesting, the carcass trait was evaluated at the slaughterhouse according to Korean standards. The carcass yield score and grade were also calculated based on revised criteria. Overall, dry matter intake, average daily gain, blood metabolites concentration, and the carcass traits, except for backfat thickness and the yield score, did not differ between the treatments. The HCP had lower backfat thickness than those of CON. There was no difference in the carcass yield grade, but the yield score was higher in the HCP treatment. According to the newly revised carcass grading criteria, both yield score and grade were higher in HCP than in CON. Increasing CP supply decreased the carcass's backfat thickness without altering growth performance and body metabolism, resulting in improved yield score and grade. Therefore, feeding a high CP diet may be beneficial in the farm income, although it may also increase feed cost and nitrogen excretion to the environment.

Keywords: Hanwoo, Finishing beef cattle, Crude protein, Growth performance, Blood metabolite, Carcass characteristics 
Competing interests

No potential conflict of interest relevant to this article was reported.

Funding sources

This research was supported by the academic research funds from Chungnam National University.

Acknowledgements

This research was supported by Cargil Agri Purina.

Availability of data and materia Upon reasonable request, the datasets of this study can be available from the corresponding author.

Authors' contributions Conceptualization: Seo J, Seo S. Data curation: Jeon S, Seo S Formal analysis: Jeon S, Lee M. Methodology: Kim JH, Kam DK, Seo S. Investigation: Lee $\mathrm{M}$.

Writing - original draft: Jeon S. Writing - review \& editing: Seo J, Seo S.

Ethics approval and consent to participate This study was conducted at the Center for Animal Science Research, Chungnam National University, Korea. Animal use and the protocols for this experiment were reviewed and approved by the Chungnam National University Animal Research Ethics Committee (CNU-00755)

\section{INTRODUCTION}

The supply of a sufficient amount of protein is critical for beef cattle production. Dietary protein maintains normal physiological functions, such as musculoskeletal maintenance and immune cell and enzyme production [1]. A sufficient dietary protein supply helps to maintain the adequate level of digestive enzymes and rumen microbes required to increase feed utilization and nutrient absorption in beef cattle $[2,3]$. Nevertheless, in the past, the importance of dietary protein level during the fattening period has often been ignored since the rate of empty body protein gain decreases, while that of fat gain increases as an animal gets closed to mature body weight (BW) [4]. Recently, however, beef cattle's mature BW has increased due to continuous genetic improvement and there has been a growing demand to increase the dietary protein level in beef cattle $[5,6]$.

Several studies have shown that feeding a high protein diet to beef cattle has positive effects on growth performance and carcass traits. Owens and Gardner [7] reported that a high crude protein (CP) diet $(13 \% \mathrm{CP})$ for beef cattle could lead to a better carcass yield and marbling score than a low $\mathrm{CP} \operatorname{diet}(11 \% \mathrm{CP})$. Lee et al. [8] reported that average daily gain (ADG) tended to be higher in the Hanwoo beef cows fed a high protein diet $(14.3 \%$ and $12.7 \%$ of $\mathrm{CP}$ at early fattening and finishing, respectively) compared with the control (12.4\% of $\mathrm{CP}$ throughout the fattening stage). In Jeong et al. [6], a high CP diet group $(14 \% \mathrm{CP})$ had a higher marbling score than the control diet $(12 \% \mathrm{CP})$. Kim et al. [9] also showed an improvement in the marbling score in Hawoo steers with a high CP feeding program (16,15, and 14\% CP during growing, fattening, and finishing periods, respectively) compared with the control $(14,13$, and $11 \%$ CP during growing, fattening, and finishing periods, respectively).Subsequently, a high level of dietary protein has become of interest to improve the carcass quality of beef cattle, and its level has been increasing in the field.

On the other hands, some other studies were against increasing CP beyond a necessary level. They suggested an excessive increase in the dietary protein level does not increase animal performance or efficiency, but rather incurs an energy cost for detoxifying excess ammonia [10]. Gleghorn et al. [11] reported quadratic effect on ADG and dry matter intake (DMI) and no difference for the gain:feed ratio with increased dietary CP contents. McBride et al. [12] indicated that as dietary $\mathrm{CP}$ concentration increased, the $\mathrm{N}$ retention efficiency decreased. Protein rich ingredients are usually expensive, so it may be an inefficient feeding strategy if there is no performance enhancement. In addition to the efficiency aspect, unused protein in the body is excreted as manure, which may increase environmental pollution [13-15]. In this regard, there is a need to know the upper level of dietary protein that positively affects growth performance and carcass traits. However, to the best of our knowledge, there is no study on how much to increase the level of dietary protein in Hanwoo beef cattle.

Therefore, this study aimed to test whether a dietary $\mathrm{CP}$ level higher than a commercial diet would improve growth performance, body metabolism, and carcass traits in Hanwoo beef cattle. We prepared two kinds of total mixed ration (TMR), which provided similar dietary energy but had different dietary protein levels. Since there is a possibility that the high dietary CP level may differ by gender and age due to differnces in body composition, the experiment was performed on beef cows, heifers, and steers, and their growth performance, blood metabolites, and carcass characteristics were analyzed.

\section{MATERIALS AND METHODS}

This study was conducted at the Center for Animal Science Research, Chungnam National University, Korea. Animal use and the protocols for this experiment were reviewed and approved by 
the Chungnam National University Animal Research Ethics Committee (CNU-00755).

\section{Experimental design, animals, and diets}

A total of 32 Hanwoo beef cattle participated in this three-month (12 weeks) feeding trial. There were 18 multiparous cows $(663 \pm 58.6 \mathrm{~kg}, 49 \pm 0.6$ months old), six heifers $(555 \pm 45.8 \mathrm{~kg}, 26 \pm 0.5$ months old), and eight steers ( $649 \pm 34.7 \mathrm{~kg}, 26 \pm 0.3$ months old). The cattle were distributed in a completely randomized block design according to gender and BW. Two cattle of the same gender and similar BW were grouped and housed in pen. Each pen $(5 \mathrm{~m} \times 5 \mathrm{~m})$ was equipped with one feed bin, which automatically measured individual feed intake by recognizing each animal using the radio-frequency identification tag attached to them (Dawoon, Incheon, Korea).

Two different TMR were prepared for this experiment. The forage sources and amounts were the same in the two TMR. The control TMR (CON) was mixed with a commercial concentrate mix containing $168 \mathrm{~g} \mathrm{CP} / \mathrm{kg}$ dry matter (DM). The high CP TMR (HCP) was prepared with a concentrate mix formulated to contain $183 \mathrm{~g} \mathrm{CP} / \mathrm{kg} \mathrm{DM}$ and the same level of metabolizable energy (ME) content as the control. The feed composition and the analyzed chemical composition of the experimental TMR are given in Tables 1 and 2, respectively. The final CP level of CON (156 g/kg $\mathrm{DM}$ ) was similar to that of a general high protein diet [16], and the final CP content of $\mathrm{HCP}$ (173 $\mathrm{g} / \mathrm{kg} \mathrm{DM}$ ) was $10 \%$ higher than that of CON. Within each block, cattle were randomly allocated to one of the two TMR treatments. The cattle were fed twice daily at 09:00 $\mathrm{h}$ and 18:00 h. The TMR, drinking water, and mineral block were freely accessible to the animals throughout the experiment.

Table 1. Diet formulation ( $\mathrm{g} / \mathrm{kg} \mathrm{DM}$ or as stated) of the experimental diets

\begin{tabular}{|c|c|c|}
\hline \multirow{2}{*}{ Item } & \multicolumn{2}{|c|}{ Treatments ${ }^{1)}$} \\
\hline & Control & $\mathrm{HCP}$ \\
\hline \multicolumn{3}{|l|}{ Ingredients } \\
\hline Tall fescue & 62 & 62 \\
\hline Ryegrass straw & 62 & 62 \\
\hline Corn (flaked) & 225 & 222 \\
\hline Corn (ground) & 58 & 26 \\
\hline Wheat (ground) & 195 & 202 \\
\hline Corn gluten feed & 192 & 170 \\
\hline DDGS & 41 & 94 \\
\hline Soy hulls & 84 & 83 \\
\hline Whole cottonseed & 28 & 27 \\
\hline Extruded linseed & 5 & 5 \\
\hline Palm oil & 2 & 3 \\
\hline Molasses & 22 & 22 \\
\hline CMS & 10 & 0 \\
\hline Urea & 0 & 8 \\
\hline $\mathrm{NH}_{4} \mathrm{Cl}$ & 2 & 2 \\
\hline Limestone & 8 & 10 \\
\hline Salt & 2 & 2 \\
\hline Vitamin and mineral $\mathrm{mix}^{2)}$ & 2 & 1 \\
\hline \multicolumn{3}{|c|}{${ }^{11}$ Control, containing $156 \mathrm{~g} / \mathrm{kg}$ DM of CP; HCP, high level of crude protein, containing $173 \mathrm{~g} / \mathrm{kg}$ DM of CP. } \\
\hline \multicolumn{3}{|c|}{$\begin{array}{l}{ }^{2} 33,330,000 \mathrm{IU} / \mathrm{kg} \text { vitamin A, 40,000,000 IU } / \mathrm{kg} \text { vitamin D, } 20.86 \mathrm{IU} / \mathrm{kg} \text { vitamin E, } 20 \mathrm{mg} / \mathrm{kg} \mathrm{Cu}, 90 \mathrm{mg} / \mathrm{kg} \mathrm{Mn}, 100 \mathrm{mg} / \mathrm{kg} \mathrm{Zn,} 250 \\
\mathrm{mg} / \mathrm{kg} \mathrm{Fe}, 0.4 \mathrm{mg} / \mathrm{kg} \mathrm{I} \text {, and } 0.4 \mathrm{mg} / \mathrm{kg} \text { Se. }\end{array}$} \\
\hline
\end{tabular}


Table 2. Analyzed chemical composition ( $\mathrm{g} / \mathrm{kg} \mathrm{DM}$ or as stated) of the experimental diets

\begin{tabular}{|c|c|c|}
\hline \multirow{2}{*}{ Item } & \multicolumn{2}{|c|}{ Treatments $^{1)}$} \\
\hline & Control & HCP \\
\hline DM ( $\mathrm{g} / \mathrm{kg}$ as fed) & 898 & 911 \\
\hline $\mathrm{OM}$ & 940 & 943 \\
\hline $\mathrm{CP}$ & 156 & 173 \\
\hline SOLP & 58 & 67 \\
\hline $\mathrm{NDICP}$ & 17 & 18 \\
\hline ADICP & 10 & 12 \\
\hline aNDF & 338 & 353 \\
\hline ADF & 162 & 188 \\
\hline ADL & 30 & 35 \\
\hline Ether extract & 44 & 55 \\
\hline Ash & 60 & 57 \\
\hline $\mathrm{Ca}$ & 8 & 9 \\
\hline$P$ & 5 & 5 \\
\hline K & 11 & 11 \\
\hline $\mathrm{Na}$ & 3 & 3 \\
\hline $\mathrm{Cl}$ & 5 & 5 \\
\hline S & 3 & 3 \\
\hline TDN & 747 & 753 \\
\hline ME (MJ/kg DM) & 11.2 & 10.8 \\
\hline NEm (MJ/kg DM) & 7.4 & 7.5 \\
\hline NEg (MJ/kg DM) & 4.7 & 4.8 \\
\hline Total carbohydrates & 740 & 715 \\
\hline NFC & 419 & 381 \\
\hline \multicolumn{3}{|c|}{ Carbohydrate fractions ( $\mathrm{g} / \mathrm{kg}$ carbohydrate) } \\
\hline $\mathrm{CA}$ & 63 & 63 \\
\hline CB1 & 430 & 393 \\
\hline CB2 & 73 & 76 \\
\hline CB3 & 336 & 350 \\
\hline $\mathrm{CC}$ & 99 & 117 \\
\hline \multicolumn{3}{|l|}{ Protein fractions (g/kg CP) } \\
\hline$P A+B 1$ & 373 & 387 \\
\hline PB2 & 520 & 510 \\
\hline PB3 & 46 & 34 \\
\hline PC & 61 & 70 \\
\hline
\end{tabular}

${ }^{1)}$ Control, containing $156 \mathrm{~g} / \mathrm{kg}$ DM of CP; HCP, high level of crude protein, containing $173 \mathrm{~g} / \mathrm{kg}$ DM of CP.

DM, dry matter; OM, organic matter; CP, crude protein; SOLP, soluble CP; NDICP, neutral detergent insoluble CP; ADICP, acid detergent insoluble $\mathrm{CP}$; aNDF, neutral detergent fiber analyzed using a heat-stable amylase and expressed inclusive of residual ash; $A D F$, acid detergent fiber; $A D L$, acid detergent lignin; TDN, total digestible nutrients; NEm, net energy for maintenance; NEg, net energy for growth; NFC, non-fiber carbohydrate; CA, carbohydrate A fraction, ethanol soluble carbohydrates; CB1, carbohydrate B1 fraction, starch; $\mathrm{CB} 2$, carbohydrate $\mathrm{B} 2$ fraction, soluble fiber; $\mathrm{CB} 3$, carbohydrate $\mathrm{B} 3$ fraction, available insoluble fiber; $\mathrm{CC}$, carbohydrate $\mathrm{C}$ fraction, unavailable carbohydrate; $\mathrm{PA}+\mathrm{B} 1$, protein $\mathrm{A}$ and $\mathrm{B} 1$ fractions, soluble $\mathrm{CP}$; $\mathrm{PB} 2$, protein $\mathrm{B} 2$ fraction, intermediate degradable $\mathrm{CP}$; $\mathrm{PB} 3$, protein $\mathrm{B} 3$ fraction, slowly degradable fiber-bound $\mathrm{CP} ; \mathrm{PC}$, protein $\mathrm{C}$ fraction, unavailable $\mathrm{CP}$ 


\section{Measurements and chemical analysis}

Daily DMI was measured throughout the 12-week feeding trial. Every four weeks, daily DMI with 2.5 times the SD above or below the mean were treated as outliers and omitted. Daily DMI were averaged over the 12 weeks. The BW was measured every four weeks before morning feeding.

The feed samples, collected every two or three weeks, were pooled and dried at $60^{\circ} \mathrm{C}$ for $96 \mathrm{~h}$. They were then ground through a cyclone mill (Foss, Hillerød, Denmark) fitted with a $1 \mathrm{~mm}$ screen before chemical analysis. The nutrient composition of the samples was analyzed at Cumberland Valley Analytical Services (Waynesboro, PA, USA). The details of the methods used to analyze the samples' nutrient contents were the same as described in Jeon et al. [17]. The dietary total digestible nutrients (TDN) was calculated according to NRC [18]. The digestible energy (DE) and $\mathrm{ME}$ contents $(\mathrm{Mcal} / \mathrm{kg})$ were assumed to be 0.004409 times TDN $(\mathrm{g} / \mathrm{kg})$ and 0.82 times DE, respectively, based on NASEM [4].

\section{Carcass characteristics and blood metabolites}

The experiment was ended when more than half of the steers reached the target body weight $(730 \mathrm{~kg}$ ). The beef cattle that reached $730 \mathrm{~kg}$ were transferred to a slaughterhouse (Nonghyup livestock joint market Eumseong center, Chungcheongbuk-do, Korea) in groups. Two months after the feeding trial was done, those that did not reach the target BW were transferred to the slaughterhouse regardless of their BW, including 17 cows, five heifers, and one steer. There was no difference in the mean experiment period (30 weeks) and the animal numbers of each gender between the treatment groups. At the slaughterhouse, the shrunk BW (SBW) of the cattle was also measured after $24 \mathrm{~h}$ fasting before slaughtering (i.e., the final BW in Table 5), which was different from the full BW on the last day of the feeding trial (i.e., the final BW in Table 3). Carcass characteristics were determined by an officer in the Korea Institute for Animal Products Quality Evaluation according to the detailed criteria for judging livestock product grades established by the Ministry of Agriculture, Food and Rural Affairs in Korea. The judging guidelines for livestock product grades changed after the judgment had been made [19]. Thus, the yield score and yield grade based on the current standards were also determined manually.

The blood of all cattle was collected a day before the first group was transferred to the slaughterhouse. Approximately $20 \mathrm{~mL}$ of blood was taken from each cattle's jugular vein and collected into a vacutainer serum tube containing a clot activator (BD Vacutainer Systems, BD, Franklin Lakes, NJ, USA). The serum tubes were placed on ice and then immediately transferred

Table 3. Effects of dietary crude protein content on intake and growth performance of Hanwoo finishers

\begin{tabular}{|c|c|c|c|c|c|c|c|c|c|c|}
\hline \multirow{2}{*}{ Item } & \multicolumn{2}{|c|}{ Diet $^{1)}$} & \multirow{2}{*}{ SEM } & \multicolumn{3}{|c|}{ Gender } & \multirow{2}{*}{ SEM } & \multicolumn{3}{|c|}{$p$-value } \\
\hline & Control & HCP & & Cow & Heifer & Steer & & Diet & Gender & Interaction \\
\hline \multicolumn{11}{|l|}{ BW (kg) } \\
\hline Final BW & 679.7 & 669.6 & 15.50 & $701.4^{\mathrm{a}}$ & $622.5^{\mathrm{b}}$ & $700.0^{\mathrm{a}}$ & 22.8 & 0.65 & 0.02 & 0.85 \\
\hline ADG $(g / d)$ & 538.5 & 558.5 & 50.65 & $406.2^{b}$ & $705.3^{\mathrm{a}}$ & $534.0^{\mathrm{ab}}$ & 89.3 & 0.78 & 0.02 & 0.41 \\
\hline MEI (Mcal/d) & 2.3 & 2.3 & 0.09 & 2.4 & 2.5 & 2.0 & 0.16 & 0.70 & 0.01 & 0.40 \\
\hline FCR & 1.8 & 1.9 & 0.29 & 2.6 & 1.5 & 1.6 & 0.5 & 0.87 & 0.04 & 0.70 \\
\hline
\end{tabular}

${ }^{1)}$ Control, containing $156 \mathrm{~g} / \mathrm{kg}$ DM of CP; HCP, high level of crude protein, containing $173 \mathrm{~g} / \mathrm{kg}$ DM of CP.

a,b Means that do not significantly differ with common superscripts within treatments $(p<0.05)$.

BW, body weight; ADG, average daily gain; DMI, dry matter intake; CPI, crude protein intake; MEI, metabolizable energy intake; FCR, feed conversion ratio. 
to the analytical laboratory to analyze the blood metabolites. The serum was analyzed for glucose, total cholesterol, triglycerides, blood urea nitrogen (BUN), creatinine, glutamic oxaloacetic transaminase (GOT), glutamate pyruvate transaminase (GPT), calcium $(\mathrm{Ca})$, inorganic phosphate (IP), magnesium $(\mathrm{Mg})$, albumin, and total protein using kits purchased from Wako Pure Chemical Industries (Osaka, Japan) and a clinical auto-analyzer (Toshiba Accute Biochemical AnalyzerTBA-40FR, Toshiba Medical Instruments, Tokyo, Japan).

\section{Statistical analysis}

The experiment was conducted using a completely randomized block design, and the data were analyzed using the GLM procedure of SAS (SAS Institute, Carey, NC, USA) [20] according to the following linear model:

$$
y_{i j k}=\mu+\tau_{i}+\rho_{j}+(\tau \rho)_{i j}+e_{i j k}
$$

Where $\mathrm{y}_{\mathrm{ijk}}$ is $\mathrm{k}^{\text {th }}$ observation in $\mathrm{i}^{\text {th }}$ treatment and the $\mathrm{j}^{\text {th }}$ gender, $\mu$ is the overall mean, $\tau_{i}$ is the fixed effect of $i^{\text {th }}$ treatment ( $\mathrm{i}=1$ to 2$), \rho_{j}$ is the fixed effect of the $\mathrm{j}^{\text {th }}$ gender $(\mathrm{j}=1$ to 3$),(\tau \rho)_{i j}$ is the fixed effect of the interaction between $i^{\text {th }}$ treatment and $j^{\text {th }}$ gender, and $\mathrm{e}_{\mathrm{ijk}}$ is the unexplained random effect on $\mathrm{k}^{\text {th }}$ observation in $\mathrm{i}^{\text {th }}$ treatment and $\mathrm{j}^{\text {th }}$ gender.

Differences between the treatments were also compared with Tukey's test when there was a significant overall treatment effect [21]. Statistical significance was declared at $p<0.05$ and a trend was discussed at $0.05 \leq p<0.1$.

\section{RESULTS AND DISCUSSION}

Feeding a sufficient amount of dietary protein during the fattening period could help feed utilization and nutrient absorption, thereby producing high-quality beef cattle [2,3]. Based on this belief, the commercial diet's dietary CP level for beef cattle has been increasing. However, studies on how much to increase the protein level are scarce. Therefore, the present study aimed to investigate whether a higher CP level than a conventional diet could improve the growth performance, body metabolism, and carcass traits in finishing beef cattle.

\section{Intake behavior and growth performance}

DMI, daily CP intake (CPI), and ME intake (MEI) did not differ by the dietary CP levels (Table 3). There is controversy over whether dietary $\mathrm{CP}$ content changes intake levels in cattle. Several studies with feedlot cattle showed no difference in feed intake with increasing $\mathrm{CP}$ content in the feed. In the Gleghorn et al. [11], who fed low-, standard-, and high-level CP diets to finishing cattle, there was no difference in DMI among the treatments. Providing the same energy level and different $\mathrm{CP}$ levels (12\% and 14\%) to the finishing steers, there was no difference between treatments [6]. In the pre- and post-partum dairy cattle, there was no difference in DMI when fed $16 \%$ or $19 \% \mathrm{CP}$ contained diet [22]. There were no differences in the finishing beef cattle according to dietary CP levels (13.2\% to $18.6 \%, 13.7 \%$ to $20.2 \%$ ) by varying the dried distiller's grain with solubles (DDGS) in the feed [23,24]. On the contrary, a few studies showed an increase in feed intake by increasing dietary CP level. When CP content was increased from $15.1 \%$ to $18.4 \%$, feed intake increased linearly in the lactating cow [25]. DMI increased linearly with dietary CP content (13.6\% to 32.7\%) by increasing the diet's DDGS content during the 130 days before slaughter [26]. Interestingly, several studies also reported a decrease in feed intake as the dietary $\mathrm{CP}$ level increased. In lactating cattle, DMI decreased linearly as the dietary CP risen from $15.6 \%$ to $18.0 \%$ [27]. 
Also, in steers, a high protein diet increased intake, but feed intake decreased with a further protein increase [28]. Oltjen et al. [29] suggested that a supply of protein that exceeds the animal's ability to convert ammonia into urea caused a decrease in feed intake. In the current study, both treatments fed high dietary protein, but it is presumed that the $\mathrm{CP}$ content was not high enough to reduce intake.

According to the diet treatment, there was no significant difference in the final BW, ADG, and feed conversion ratio (FCR), even though growth performance differed by gender as expected (Table 3). These results were consistent with other studies. In finishing cattle, the dietary protein level did not affect ADG and FCR [30,31]. In the study in which CP content was differed by different DDGS contents, there was no difference in ADG according to CP content [26]. There was also no effect on $\mathrm{ADG}$ and feed efficiency according to the dietary $\mathrm{CP}$ level in the growingfinishing beef cattle [32]. According to the dietary protein level, there was no difference in the BW gain in lactating dairy cows [25]. In the study of Buckner et al. [24], there was no difference in feed efficiency, but ADG increased until 14.4\% of CP and then decreased (14.4\% to 18.6\%). They argued that an increase in dietary $\mathrm{CP}$ promoted growth as long as energy supply was not limited, but the growth rate was reversed as the amount of available protein exceeded available energy since the energy that is required to discharge excessive nitrogen. In the present study, however, additional dietary $\mathrm{CP}$ levels did not reduce the cattle's growth rate. The dietary $\mathrm{CP}$ levels might not be high enough to retard the cattle's growth although both were high. Initial BW was the highest in adult cows, and steer had a higher weight than heifers despite the same age. At the end of the experiment, cows and steers showed similar BW, while heifers had lower weight than the other two genders $(p<$ $0.05)$.

\section{Blood metabolites}

No statistically significant difference was seen in any of the energy and protein metabolism indicators in the blood (Table 4). The most common observation with an increase in dietary CP is elevated concentrations of total protein, BUN, or both in the blood [25,33]. However, we did not observe this phenomenon in this study, although BUN concentration was numerically higher in the HCP group than in CON (19.5 mg/dL vs. $17.8 \mathrm{mg} / \mathrm{dL}$, Table 4). This is probably because the actual CPI between the two treatments did not significantly differ because of numerical reduction in feed intake in the HCP group (Table 3).

Total protein concentration in the current study was similar to the typical range of values in Hanwoo, 6.5-7.5 g/dL, reported by Cho et al. [34]. However, the concentration of BUN in this study was higher than a typical range of values in Hanwoo, 8-14 mg/dL [34]. This was expected because BUN concentration is related to the protein-to-energy ratio [35], and the dietary proteinto-energy ratio in this study was higher than in typical situations. This study's protein-to-energy ratios were $58 \mathrm{~g} / \mathrm{Mcal}$ and $67 \mathrm{~g} / \mathrm{Mcal}$ for $\mathrm{CON}$ and $\mathrm{HCP}$, respectively, which were higher than a typical value (42-46 g/Mcal) in Hanwoo [36]. Nonetheless, it is not uncommon to have a BUN concentration higher than $18 \mathrm{mg} / \mathrm{dL}$ in Hanwoo beef cattle [37].

\section{Carcass characteristics}

The backfat thickness was lower in HCP than in CON, although carcass weight, rib eye area, marbling score, and the meat and fat color scores did not significantly differ (Table 5). Due to a lower backfat thickness, the yield score was higher in HCP than in CON $(p<0.05)$, but the yield score did not increase enough to improve the yield grade $(p>0.05)$. However, when we apply the recently revised grading system of beef carcasses, which is the most sensitive to backfat thickness [38], both the yield score and grade improved in $\mathrm{HCP}$ than $\mathrm{CON}(p<0.05)$. The underlying 
Table 4. Effects of dietary crude protein contents on blood metabolites

\begin{tabular}{|c|c|c|c|c|c|c|c|c|c|c|}
\hline \multirow{2}{*}{ Item } & \multicolumn{2}{|c|}{ Diet $^{1)}$} & \multirow{2}{*}{ SEM } & \multicolumn{3}{|c|}{ Gender } & \multirow{2}{*}{ SEM } & \multicolumn{3}{|c|}{$p$-value } \\
\hline & Control & HCP & & Cow & Heifer & Steer & & Diet & Gender & Interaction \\
\hline Glucose (mg/dL) & 65.62 & 83.28 & 9.054 & 62.76 & 89.17 & 71.42 & 13.307 & 0.18 & 0.24 & 0.06 \\
\hline Total cholesterol (mg/dL) & 166.99 & 159.39 & 9.433 & $133.05^{b}$ & $188.83^{\mathrm{a}}$ & $167.70^{\mathrm{ab}}$ & 13.864 & 0.57 & $<0.01$ & 0.31 \\
\hline Triglycerides (mg/dL) & 16.26 & 20.78 & 2.181 & $20.68^{\mathrm{a}}$ & $23.33^{\mathrm{a}}$ & $11.56^{\mathrm{b}}$ & 3.206 & 0.15 & 0.02 & 0.25 \\
\hline BUN (mg/dL) & 17.80 & 19.47 & 0.803 & $17.34^{b}$ & $21.80^{\mathrm{a}}$ & $16.76^{b}$ & 1.180 & 0.16 & 0.01 & 0.12 \\
\hline Creatinine (mg/dL) & 1.35 & 1.38 & 0.061 & 1.28 & 1.44 & 1.38 & 0.090 & 0.77 & 0.26 & 0.62 \\
\hline GOT (IU/L) & 116.98 & 123.89 & 8.399 & 122.04 & 138.92 & 100.35 & 12.344 & 0.57 & 0.07 & 0.25 \\
\hline GPT (IU/L) & 17.73 & 17.75 & 0.749 & 17.38 & 18.79 & 17.03 & 1.100 & 0.99 & 0.45 & 0.06 \\
\hline $\mathrm{Ca}(\mathrm{mg} / \mathrm{dL})$ & 8.88 & 8.91 & 0.271 & 8.76 & 9.03 & 8.89 & 0.398 & 0.93 & 0.83 & 0.82 \\
\hline IP (mg/dL) & 6.19 & 6.32 & 0.234 & $5.52^{\mathrm{b}}$ & $6.77^{\mathrm{a}}$ & $6.48^{\mathrm{a}}$ & 0.344 & 0.70 & $<0.01$ & 0.29 \\
\hline $\mathrm{Mg}(\mathrm{mg} / \mathrm{dL})$ & 2.10 & 2.08 & 0.083 & $1.87^{\mathrm{b}}$ & $2.25^{\mathrm{a}}$ & $2.15^{\mathrm{ab}}$ & 0.122 & 0.84 & 0.02 & 0.58 \\
\hline Albumin (g/dL) & 3.13 & 3.19 & 0.099 & 3.10 & 3.27 & 3.10 & 0.145 & 0.69 & 0.61 & 0.70 \\
\hline Total protein (g/dL) & 6.46 & 6.58 & 0.240 & 6.69 & 6.52 & 6.36 & 0.353 & 0.73 & 0.67 & 0.69 \\
\hline Total bilirubin (mg/dL) & 0.02 & 0.02 & 0.009 & 0.03 & 0.03 & $<0.01$ & 0.014 & 0.87 & 0.18 & 0.29 \\
\hline
\end{tabular}

${ }^{11}$ Control, containing $156 \mathrm{~g} / \mathrm{kg}$ DM of CP; HCP, high level of crude protein, contained $173 \mathrm{~g} / \mathrm{kg}$ DM of CP.

$a, b$ Means that do not significantly differ with common superscripts within treatments $(p<0.05)$

BUN, blood urea nitrogen; GOT, glutamic oxaloacetic transaminase; GPT, glutamate pyruvate transaminase; IP, inorganic phosphate.

Table 5. Effects of dietary crude protein content on carcass characteristics of Hanwoo cattle

\begin{tabular}{|c|c|c|c|c|c|c|c|c|c|c|}
\hline \multirow{2}{*}{ Item } & \multicolumn{2}{|c|}{ Diet $^{1)}$} & \multirow{2}{*}{ SEM } & \multicolumn{3}{|c|}{ Gender } & \multirow{2}{*}{ SEM } & \multicolumn{3}{|c|}{$p$-value } \\
\hline & Control & HCP & & Cow & Heifer & Steer & & Diet & Gender & Interaction \\
\hline Final SBW (kg) & 717.7 & 707.9 & 13.75 & 718.8 & 698.3 & 721.3 & 20.20 & 0.62 & 0.64 & 0.95 \\
\hline Carcass weight $(\mathrm{kg})$ & 432.7 & 421.3 & 8.70 & 424.9 & 421.5 & 434.5 & 12.79 & 0.36 & 0.70 & 0.97 \\
\hline Marbling score & 61.6 & 57.4 & 4.98 & 58.2 & 54.3 & 66.0 & 7.33 & 0.55 & 0.45 & 0.93 \\
\hline Meat color & 5.00 & 4.93 & 0.103 & 5.06 & 4.83 & 5.00 & 0.151 & 0.61 & 0.45 & 0.45 \\
\hline Fat color & 3.07 & 3.16 & 0.132 & 3.22 & 3.00 & 3.13 & 0.194 & 0.66 & 0.60 & 0.81 \\
\hline Quality grade & 2.26 & 2.45 & 0.221 & 2.44 & 2.50 & 2.13 & 0.325 & 0.54 & 0.59 & 0.88 \\
\hline Back fat (mm) & 21.9 & 17.0 & 1.49 & $22.4^{a}$ & $23.5^{\mathrm{a}}$ & $12.5^{\mathrm{b}}$ & 2.19 & 0.03 & $<0.01$ & 0.79 \\
\hline Rib eye area $\left(\mathrm{cm}^{2}\right)$ & 95.8 & 96.3 & 2.40 & 95.3 & 98.2 & 94.6 & 3.53 & 0.90 & 0.73 & 0.16 \\
\hline Yield score ${ }^{2)}$ & 59.7 & 63.3 & 0.97 & $59.6^{b}$ & $59.3^{\mathrm{b}}$ & $65.5^{\mathrm{a}}$ & 1.42 & 0.01 & $<0.01$ & 0.69 \\
\hline Yield grade ${ }^{2)}$ & 2.67 & 2.37 & 0.156 & $2.89^{\mathrm{a}}$ & $2.67^{\mathrm{ab}}$ & $2.00^{\mathrm{b}}$ & 0.230 & 0.19 & $<0.01$ & 0.55 \\
\hline Yield score_20193) & 58.7 & 60.1 & 0.38 & $58.7^{\mathrm{b}}$ & $58.8^{\mathrm{b}}$ & $60.8^{\mathrm{a}}$ & 0.56 & 0.02 & 0.01 & 0.52 \\
\hline Yield grade_20193) & 2.71 & 2.18 & 0.147 & $2.67^{\mathrm{a}}$ & $2.67^{\mathrm{ab}}$ & $2.00^{b}$ & 0.216 & 0.02 & 0.02 & 0.91 \\
\hline
\end{tabular}

${ }^{11}$ Control, contained $156 \mathrm{~g} / \mathrm{kg} \mathrm{DM}$ of CP; HCP, high level of crude protein, contained $173 \mathrm{~g} / \mathrm{kg}$ DM of CP.

${ }^{2}$ Yield score $=68.184-0.625 \times$ back fat $+0.130 \times$ rib eye area $-0.024 \times$ carcass weight +3.23 ; A grade, $>67.20 ; \mathrm{B}$ grade, 63.30 $\sim 67.20 ; \mathrm{C}$ grade, $<63.30$.

${ }^{3}$ Based on the revised beef grading system in 2019; Yield score for cow and heifer $=(6.90137-0.9446 \times$ back fat $+0.31805 \times$ rib eye area $+0.54952 \times$ carcass weight $) /$ (carcass weight $\times 100)$; Yield score for steer $=(11.06398-1.25149 \times$ back fat $+0.28293 \times$ rib eye area $+0.56781 \times$ carcass weight $) /($ carcass weight $\times 100) ;$ A grade, $>61.83$ (cow and heifer) and > 62.52 (steer); B grade, 59.70-61.83 (cow and heifer) and 60.40-62.52 (steer); C grade, $<59.70$ (cow and heifer) and $<60.40$ (steer).

a,b Means that do not significantly differ with common superscripts within treatments $(p<0.05)$.

SBW, shrunk body weight; Quality grade, numerical conversion of quality grades $(1,2,3,4$, and 5 correspond to the 1++, 1+, 1, 2, and 3 grades, respectively); Yield grade, numerical conversion of yield grades $(1,2$, and 3 correspond to the $\mathrm{A}, \mathrm{B}$, and $\mathrm{C}$ grades, respectively).

mechanism of reducing backfat thickness due to increased dietary $\mathrm{CP}$ needs to be deciphered. In several studies, the backfat thickness was not affected by the dietary protein level [11,30]. In a study in which the dietary protein content was varied from $14 \%$ to $20 \%$ by increasing the inclusion rate of DDGS in the diet from 0\% to 75\%, there was no difference in backfat thickness [39]. Some studies even showed that the higher CP could increase the backfat thickness. The review by Galyean 
[5] indicated that a diet with 14\% CP tended to have thicker backfat than that with $11 \%$ CP. On the contrary, some studies reported a thinner backfat due to a higher level of dietary CP. The high protein $(14 \% \mathrm{CP})$ fed group had thinner backfat compared to the control $(12 \% \mathrm{CP})$ group in Hanwoo steers [6]. Gibb et al. [26] also showed that the high CP (20.0\% CP) diet decreased backfat thickness compared to the low $\mathrm{CP}(13.6 \%$ of $\mathrm{CP})$ diet. In their study, the dietary $\mathrm{CP}$ level was increased by increasing the level of DDGS content in the diet as our study. In some cases, DDGS caused thinner backfat thickness due to the DDGS itself or increased the ether extract (EE) contents $[26,40,41]$. However, the studies that fed iso-nitrous with different DDGS contents to lambs showed no difference in the backfat thickness according to the DDGS level or the EE contents $[40,41]$.

A high protein diet did not increase the degree of marbling in our study, although Kim et al. [9] reported a higher marbling score in the high protein diet than in the control group. It has been argued that an increase in dietary protein level can improve starch digestion and absorption in the small intestine, which results in an increase in the blood insulin and glucose levels $[2,42]$. In this study, however, the starch level of HCP (281 g/kg DM) was $11.7 \%$ lower than that of the control $(318 \mathrm{~g} / \mathrm{kg} \mathrm{DM})$, and thus an improvement in marbling by increasing starch supply did not likely occur.

Overall, feeding HCP for the last three months of the finishing period did not affect DMI and BW gains in Hanwoo beef cattle. However, HCP decreased the backfat thickness significantly, resulting in a higher carcass yield score and yield grade according to the revised beef grading system. Thus, it is possible to expect a better beef grade by providing additional dietary $\mathrm{CP}$ than a conventional diet in the finishing period. However, feeding a high protein diet may increase the feeding cost. Besides, if dietary $\mathrm{CP}$ increases, the $\mathrm{CP}$ not used for the body protein deposition is excreted as feces and urine. Not only does the animal have to spend additional energy for nitrogen excretion, but also nitrogen excretion to the environment is undesirable economically and environmentally. Thus, the economic analysis and assessment of environmental impacts need to be done to evaluate the effects of increasing dietary $\mathrm{CP}$ in the finishing beef cattle. Further research is also necessary to elucidate the underlying mechanism by which a high $\mathrm{CP}$ diet reduces backfat thickness.

We concluded that increasing the amount of dietary protein did not affect DMI, growth performance, and carcass quality indexes. However, a diet containing higher protein than a conventional one decreased the backfat thickness, resulting in higher carcass yield indexes. Therefore, feeding a high CP diet may be beneficial in the farm income. However, it may not be a sustainable practice since it may increase feed cost and nitrogen excretion to the environment.

\section{REFERENCES}

1. Marcondes MI, Gionbelli MP, Valadares Filho SC, Chizzotti ML, Paulino MF. Protein requirements of Zebu beef cattle. In: Valadares Filho SC, Marcondes MI, Chizzotti ML, Paulino MF, editors. Nutrient requirements of zebu beef cattle BR-CORTE. Vicosa: Federal Univeristy of Vicosa; 2010. p. 107-26.

2. Pethick D, McIntyre B, Tudor G. The role of dietary protein as a regulator of the expression of marbling in feedlot cattle (WA). North Sydney, Australia: Meat and Livestock Australia; 2000. Project No.: FLOT.209.

3. Jami E, White BA, Mizrahi I. Potential role of the bovine rumen microbiome in modulating milk composition and feed efficiency. PLOS ONE. 2014;9:e85423. https://doi.org/10.1371/ journal.pone. 0085423 
4. NASEM [National Academies of Sciences, Engineering, and Medicine]. Nutrient requirements of beef cattle. 8th rev. ed. Washington, DC: The National Academies Press; 2016.

5. Galyean ML. Protein levels in beef cattle finishing diets: industry application, university research, and systems results.J Anim Sci. 1996;74:2860-70. https://doi.org/10.2527/1996.74112860x

6. Jeong J, Seong NI, Hwang IK, Lee SB, Yu MS, Nam IS, et al. Effects of level of CP and TDN in the concentrate supplement on growth performances and carcass characteristics in Hanwoo steers during final fattening period. J Anim Sci Technol. 2010;52:305-12. https://doi. org/10.5187/JAST.2010.52.4.305

7. Owens FN, Gardner BA. A review of the impact of feedlot management and nutrition on carcass measurements of feedlot cattle. J Anim Sci. 2000;77:1-18. https://doi.org/10.2527/ jas2000.00218812007700ES0034x

8. Lee DH, Yoon WJ, Choi NJ, Ryu KS, Oh YK, Jang SS, et al. Effects of high protein diet on meat productivity and quality in multiparous Hanwoo cull cows. J Life Sci. 2011;21:1251-8. https://doi.org/10.5352/JLS.2011.21.9.1251

9. Kim BK, Oh DY, Hwang EG, Song YH, Lee SO, Jung KK, et al. The effects of different crude protein levels in the concentrates on carcass and meat quality characteristics of Hanwoo steers. J Anim Sci Technol. 2013;55:61-6. https://doi.org/10.5187/JAST.2013.55.1.61

10. Sinclair KD, Garnsworthy PC, Mann GE, Sinclair LA. Reducing dietary protein in dairy cow diets: implications for nitrogen utilization, milk production, welfare and fertility. Animal. 2014;8:262-74. https://doi.org/10.1017/S1751731113002139

11. Gleghorn JF, Elam NA, Galyean ML, Duff GC, Cole NA, Rivera JD. Effects of crude protein concentration and degradability on performance, carcass characteristics, and serum urea nitrogen concentrations in finishing beef steers. J Anim Sci. 2004;82:2705-17. https://doi. org/10.2527/2004.8292705x

12. McBride KW, Greene LW, Cole NA, McCollum III FT, Galyean ML. Nitrogen and phosphorus utilization by beef cattle fed three dietary crude protein levels with three levels of supplemental urea. In: Proceedings of the Plains Nutrition Council Spring Conference; 2003; San Antonio,TX.p. 114.

13. Guo K, Zoccarato I. A dynamic model to predict the nitrogen excretion in growing-finishing cattle. Ecol Modell. 2005;187:219-31. https://doi.org/10.1016/j.ecolmodel.2004.10.017

14. James T, Meyer D, Esparza E, Depeters EJ, Perez-Monti H. Effects of dietary nitrogen manipulation on ammonia volatilization from manure from Holstein heifers. J Dairy Sci. 1999;82:2430-9. https://doi.org/10.3168/jds.S0022-0302(99)75494-9

15. Vasconcelos JT, Tedeschi LO, Fox DG, Galyean ML, Greene LW. Feeding nitrogen and phosphorus in beef cattle feedlot production to mitigate environmental impacts. Prof Anim Sci. 2007;23:8-17. https://doi.org/10.1532/S1080-7446(15)30942-6

16. Samuelson KL, Hubbert ME, Galyean ML, Löest CA. Nutritional recommendations of feedlot consulting nutritionists: the $2015 \mathrm{New}$ Mexico State and Texas Tech University survey. J Anim Sci. 2016;94:2648-63. https://doi.org/10.2527/jas.2016-0282

17. Jeon S, Jeong S, Lee M, Seo J, Kam DK, Kim JH, et al. Effects of reducing inclusion rate of roughages by changing roughage sources and concentrate types on intake, growth, rumen fermentation characteristics, and blood parameters of Hanwoo growing cattle (Bos taurus coreanae). Asian-Australas J Anim Sci. 2019;32:1705-14. https://doi.org/10.5713/ajas.19.0269

18. NRC [National Research Council]. Nutrient requirements of dairy cattle. 7th rev. ed. Washington, DC: The National Academies Press; 2001.

19. MAFRA [Ministry of Agriculture, Food and Rural Affairs]. Judging guidelines of livestock product grades [Internet]. 2019 [cited 2021 Apr 5]. https://www.law.go.kr/LSW/admRul- 


\section{LsInfoP.do?admRulSeq=2100000196314}

20. SAS. SAS/OR 9.3 user's guide: mathematical programming examples. Cary, NC: SAS Institute; 2012.

21. Seo S, Jeon S, Ha JK. Guidelines for experimental design and statistical analyses in animal studies submitted for publication in the Asian-Australasian Journal of Animal Sciences. Asian-Australas J Anim Sci. 2018;31:1381-6. https://doi.org/10.5713/ajas.18.0468

22. Komaragiri MVS, Erdman RA. Factors affecting body tissue mobilization in early lactation dairy cows. 1. Effect of dietary protein on mobilization of body fat and protein. J Dairy Sci. 1997;80:929-37. https://doi.org/10.3168/jds.S0022-0302(97)76016-8

23. He ML, Xu L, Yang WZ, Gibb D, McAllister TA. Effect of low-oil corn dried distillers' grains with solubles on growth performance, carcass traits and beef fatty acid profile of feedlot cattle. Can J Anim Sci. 2014;94:343-7. https://doi.org/10.4141/cjas2013-196

24. Buckner CD, Mader TL, Erickson GE, Colgan SL, Mark DR, Karges KK, et al. Evaluation of dry distillers grains plus solubles inclusion on performance and economics of finishing beef steers. Prof Anim Sci. 2008;24:404-10. https://doi.org/10.15232/S1080-7446(15)30884-6

25. Broderick GA. Effects of varying dietary protein and energy levels on the production of lactating dairy cows. J Dairy Sci. 2003;86:1370-81. https://doi.org/10.3168/jds.S00220302(03)73721-7

26. Gibb DJ, Hao X, McAllister TA. Effect of dried distillers' grains from wheat on diet digestibility and performance of fe edlot cattle. Can J Anim Sci. 2008;88:659-65. https://doi. org/10.4141/CJAS08040

27. Bahrami-Yekdangi H, Khorvash M, Ghorbani GR, Alikhani M, Jahanian R, Kamalian E. Effects of decreasing metabolizable protein and rumen-undegradable protein on milk production and composition and blood metabolites of Holstein dairy cows in early lactation. J Dairy Sci. 2014;97:3707-14. https://doi.org/10.3168/jds.2013-6725

28. Fenderson CL, Bergen WG. Effect of excess dietary protein on feed intake and nitrogen metabolism in steers. J Anim Sci. 1976;42:1323-30. https://doi.org/10.2527/jas1976.4251323x

29. Oltjen RR, Slyter LL, Wilson RL. Urea levels, protein and diethylstilbestrol for growing steers fed purified diets. J Nutr. 1972;102:479-88. https://doi.org/10.1093/jn/102.4.479

30. Beliveau RM, McKinnon JJ. Effect of graded levels of wheat-based dried distillers' grains with solubles on performance and carcass characteristics of feedlot steers. Can J Anim Sci. 2008;88:677-84. https://doi.org/10.4141/CJAS08045

31. Buttrey EK, Cole NA, Jenkins KH, Meyer BE, McCollum III FT, Preece SLM, et al. Effects of twenty percent corn wet distillers grains plus solubles in steam-flaked and dry-rolled cornbased finishing diets on heifer performance, carcass characteristics, and manure characteristics. J Anim Sci. 2012;90:5086-98. https://doi.org/10.2527/jas.2012-5198

32. Leupp JL, Lardy GP, Bauer ML, Karges KK, Gibson ML, Caton JS, et al. Effects of distillers dried grains with solubles on growing and finishing steer intake, performance, carcass characteristics, and steak color and sensory attributes. J Anim Sci. 2009;87:4118-24. https://doi. org/10.2527/jas.2009-2149

33. Rusche WC, Cochran RC, Corah LR, Stevenson JS, Harmon DL, Brandt RT, et al. Influence of source and amount of dietary protein on performance, blood metabolites, and reproductive function of primiparous beef cows. J Anim Sci. 1993;71:557-63. https://doi. org/10.2527/1993.713557x

34. Cho HU, Ko WS, Son HW, Lee MJ, Song HJ, Park JH. Hematological and biochemical analysis of Korean indigenous cattle according to the ages. Koeran J Vet Serv. 2008;31:137-47.

35. Hammond AC. Update on BUN and MUN as a guide for protein supplementation in cattle. 
In: Proceedings of the Florida Ruminant Nutrition Symposium; 1997; Gainesville, FL. p. 43-52.

36. NIAS [National Institute of Animal Science]. Korean feeding standard for Hanwoo. 4th ed. Wanju: Rural Development Administration; 2017.

37. Jang SS, Yang SH, Lee EM, Kang DH, Park BH, Kim HJ, et al. Change of performance, serum metabolite, and carcass characteristics on high energy diet of Hanwoo steers. Korean J Agric Sci. 2016;43:810-7. https://doi.org/10.7744/kjoas.20160085

38. Cho H, Jung YB, Kim BD, Jung S, Seo S. Assessment of the effects of carcass traits and slaughter age on the carcass grades of Hanwoo steers based on the revised grading system of beef carcass. J Agric Life Sci. 2020;54:69-76. https://doi.org/10.14397/jals.2020.54.2.69

39. Gordon CM, Gosch J, Sindt JJ, Montgomery SP, Pike JN, Kessen TJ, Sulpizio MJ, Spire MF, Higgins JJ, Drouillard JS. Dakota Gold ${ }^{\circledR}$-Brand dried distiller's grains with solubles: Effects on finishing performance and carcass characteristics. Kans Agric Exp Stn Res Rep. 2002;1:27-9. https://doi.org/10.4148/2378-5977.1683

40. Whitney TR, Braden KW. Substituting corn dried distillers grains for cottonseed meal in lamb finishing diets: carcass characteristics, meat fatty acid profiles, and sensory panel traits. Sheep Goat Res J. 2010;25:49-56.

41. Abdelrahim GM, Khatiwada J, Gurung NK. Effects of dried distillers grains with solubles on performance and carcass characteristics of lamb. J Anim Res Technol. 2014;1:25-30. https:// doi.org/10.5147/jart.v1i2.106

42. Owens FN, Zinn RA, Kim YK. Limits to starch digestion in the ruminant small intestine. J Anim Sci. 1986;63:1634-48. https://doi.org/10.2527/jas1986.6351634x 